\title{
Evaluation of the Catalyzed Photo-Cold Vapour Generation for Determination of Mercury by AAS
}

\author{
Henryk Matusiewicz* and Ewa Stanisz \\ Department of Analytical Chemistry, Politechnika Poznańska, Piotrowo 5, 60-965 Poznań, Poland
}

\begin{abstract}
Nanopartículas de $\mathrm{Ag}$ suportadas em $\mathrm{TiO}_{2}\left(\mathrm{Ag}-\mathrm{TiO}_{2}\right)$ foram usadas como catalisador na geração de vapor frio induzida por radiação UV com ácido fórmico, acoplado à absorção atômica para determinação do mercúrio total em amostras analíticas. A atividade redutora de $\mathrm{Ag}-\mathrm{TiO}_{2}$ foi comparada com dois catalisadores semicondutores: $\mathrm{TiO}_{2}$ não modificado e $\mathrm{ZnO}$. O efeito do tipo de catalisador, sua concentração na amostra analisada, pH da amostra, concentração do ácido fórmico e tempo de irradiação ultravioleta foi investigado. Na presença de ácido fórmico, $\mathrm{Ag}^{-\mathrm{TiO}_{2}}$ foi o mais eficiente na redução de mercúrio. Nas condições experimentais otimizadas, a recuperação de mercúrio em quatro materiais de referência contendo $0,20-1,99 \mu \mathrm{g} \mathrm{g}^{-1} \mathrm{Hg}$ foi de 95-99\% dos valores certificados. O desvio padrão relativo para amostras foi igual ou melhor do que $11 \%$. A análise de materiais de referência certificados (correspondentes a amostras ambientais e biológicas) mostrou a potencialidade do método Ag- $\mathrm{TiO}_{2}-\mathrm{UV}-\mathrm{CVGAAS}$ na determinação de mercúrio em amostras analíticas no nível de ultra-traço.
\end{abstract}

Nano-Ag particles loaded on $\mathrm{TiO}_{2}\left(\mathrm{Ag}-\mathrm{TiO}_{2}\right)$ were used as catalyst for the UV-induced cold vapour generation with formic acid coupled to atomic absorption for determination of total mercury in analytical samples. The reducing activity of $\mathrm{Ag}-\mathrm{TiO}_{2}$ was compared with two semiconductor catalysts: unmodified $\mathrm{TiO}_{2}$ and $\mathrm{ZnO}$. The effect of catalyst type, its concentration in the analyzed sample, sample $\mathrm{pH}$, formic acid concentration and ultraviolet irradiation time have been investigated. In the presence of formic acid, most effective in the reduction of mercury was $\mathrm{Ag}-\mathrm{TiO}_{2}$. Under the optimized experimental conditions recovery of mercury in four reference materials containing $0.20-1.99 \mu \mathrm{g} \mathrm{g}^{-1} \mathrm{Hg}$ was $95-99 \%$ of certificate values. The relative standard deviation for samples was equal to or better than $11 \%$. Certified reference materials (corresponding to biological and environmental samples) analysis using the $\mathrm{Ag}-\mathrm{TiO}_{2}-\mathrm{UV}-\mathrm{CVGAAS}$ method revealed that it is promising for mercury determination in analytical samples at ultratrace level.

Keywords: photocatalytic reduction, UV-induced cold vapour generation, mercury determination, nano-Ag- $\mathrm{TiO}_{2}$

\section{Introduction}

Mercury occurs naturally in the earth's crust and undergoes complex changes in a number of cycles in the environment caused by natural and human-induced activities. The amount of mercury mobilized and released into the biosphere has increased since the beginning of the industrial age. ${ }^{1,2}$ Most of the mercury in the atmosphere is elemental mercury vapour, which circulates in the atmosphere for up to a year and therefore can be widely dispersed and transported thousands of miles from sources of emission. Most of the mercury in water, soil, sediments,

*e-mail: henryk.matusiewicz@put.poznan.pl plants, and animals is in the form of inorganic mercury salts and organic forms of mercury (e.g., methylmercury). ${ }^{3}$

Therefore, method development for the cost-effective, fast and sensitive determination of mercury in environmental and biological materials has been vigorous in recent years. The preferred method of mercury determination has been mercury cold vapour generation (CVG) and several reductants have been investigated for the reduction of $\mathrm{Hg}(\mathrm{II})$ to $\mathrm{Hg}(0)$, most frequently, sodium/potassium tetrahydroborate (THB) ${ }^{4-7}$ and stannous chloride..$^{8-11}$

Determination of mercury utilizing CVG requires a large amount of concentrated chemical reductants causing contamination of analyzed samples and forming a large amount of gaseous by-products and waste. The solution 
to these problems is to reduce analytes using UV and/or ultrasound in the presence of low molecular weight organic compounds (LMW). This method helps to decrease the consumption of chemical reductants and limit the amount of waste, making this method less costly and more "green" than traditional chemical vapour generation. ${ }^{12}$

It is well known that during UV-induced vapour generation, photo-generated electron donors, such as $\mathrm{H}^{*}$ and $\mathrm{CO}^{*}$ can contribute to the reduction of several metal ions to their corresponding volatile species. First reports on the use of UV-induced vapour generation refer to the reduction of selenium. In 2000 Kikuchi and Sakamoto ${ }^{13}$ reported the photo-reduction of selenate ions in an aqueous solution in the presence of formic acid and $\mathrm{TiO}_{2}$ as photocatalyst. Four years later Wang et al. ${ }^{14}$ studied new $\mathrm{UV} / \mathrm{TiO}_{2}$ photo-catalysis reduction device for reduction of selenium(VI) involving formic acid and nano- $\mathrm{TiO}_{2}$ as a catalyst.

Sturgeon's research group is an undisputed pioneer in the field of photo-CVG as an effective sample introduction method for analytical atomic spectrometry during the past seven years. ${ }^{15-21}$ To date, selenium, ${ }^{15,21,22}$ arsenic, ${ }^{23}$ nickel, ${ }^{18,24}$ iodine, ${ }^{19}$ cobalt, ${ }^{25}$ iron, ${ }^{20}$ and other analytes such as $\mathrm{Ag}, \mathrm{Au}$, $\mathrm{Bi}, \mathrm{Cd}, \mathrm{Cu}, \mathrm{Pb}, \mathrm{Pd}, \mathrm{Pt}, \mathrm{Rh}, \mathrm{S}, \mathrm{Sb}, \mathrm{Sn}$ and $\mathrm{Te}^{16,17}$ have been successfully converted to corresponding volatile species by using various photo-CVG systems.

In recent years increasing interest in mercury vapour generation in non-tetrahydroborate media is observed. ${ }^{26-36}$ In 2005 Zheng et al. ${ }^{26}$ successfully detected $\mathrm{Hg}$ (II) following photo-CVG in formic acid coupled to AFS. For the same purpose Bendl et al. ${ }^{27}$ used UV-CVG in acetic acid in QT-AAS system. Vieira et $a l .{ }^{28}$ used both of these acids for the determination of methylmercury and total mercury in biological samples. Gil et al..$^{29}$ and Ribeiro et al. ${ }^{30}$ utilized ultrasonic field in aqueous medium containing acetic and formic acids.

Bendicho and co-workers ${ }^{29,31}$ combined photo-CVG with ultrasound-assisted gas-liquid separation for improved determination of mercury in marine biological tissues.

Apart from acetic and formic acids, other LMW organic compounds were also found to be efficient for reduction of mercury following UV irradiation. Hou's group $^{32}$ reported on a systematic study of photo-CVG of mercury using LMW alcohols, aldehydes and carboxylic acids e.g., methanol, formaldehyde, acetaldehyde, glycol, 1,2-propanediol, glycerol and acetic, oxalic, and malonic acids. Yin et al..$^{33}$ used mercaptoethanol as precursor for UV-reduction. Photo-CVG, was also demonstrated as green analytical method for the determination of mercury in wine, liquor ${ }^{34}$ or white vinegar ${ }^{35}$ samples, directly using the sample matrix as a reductant, without any additional chemical. ${ }^{36}$
Presently, photo-reduction with catalysts usually assists treatment of drinking water and industrial wastewater by the distribution of organic pollutants. Khalil et al. ${ }^{37}$ used a $\mathrm{UV} / \mathrm{TiO}_{2}$ system to remove $\mathrm{Hg}$ (II) salts from water and found that the photo-reduction efficiency was enhanced by the addition of methanol, which served as an $\mathrm{H}^{+}$scavenger. For a similar purpose in addition to $\mathrm{TiO}_{2}$, the following semiconductor materials are commonly used under visible or UV radiation: $\mathrm{Ag}-\mathrm{TiO}_{2}, \mathrm{ZnO}, \mathrm{CdS}$ or $\mathrm{WO}_{3}{ }^{38-40}$ The photocatalytic method is based on the reactive properties of an electron-hole pair generated in the semiconductor when irradiated by UV-Vis light having energy greater than the band-gap energy of the semiconductor.

Several investigations on catalyzed photo-reduction of mercury in the field of analytical chemistry have been reported in the recent years. ${ }^{26,32,34,41}$ For this purpose, mostly $\mathrm{TiO}_{2}$ was used. Yin et al. ${ }^{41}$ reported a method for direct vapour generation of mercury species on nano- $\mathrm{TiO}_{2}$ under UV irradiation in the presence of formic acid-sodium mixture as a hole scavenger. Mercury species were detected by atomic fluorescence spectrometry after chromatographic separation (HPLC). Han et al. ${ }^{32}$ studied photo-reduction of $\mathrm{Hg}(\mathrm{II})$ in nano- $\mathrm{TiO}_{2}$-catalyzed-CVGAFS system with organic reductants such as glycol, 1,2-propanediol, glycerol, oxalic acid or malonic acid.

In this work a new UV-induced cold vapour generation of mercury with $\mathrm{Ag}$-loaded $\mathrm{TiO}_{2}\left(\mathrm{Ag}-\mathrm{TiO}_{2}\right)$ and formic acid for the determination in environmental and biological samples is reported. The photocatalytic activity of $\mathrm{TiO}_{2}$, $\mathrm{Ag}-\mathrm{TiO}_{2}$ and $\mathrm{ZnO}$ for reduction of mercury was compared. Based on the new reaction and atomic absorption spectrometric detection an environmentally friendly, cost effective and sensitive determination technique is presented.

\section{Experimental}

Instrumentation

The instrumentation for CVAAS utilizing UV-induced reduction was detailed in previous work $\mathrm{k}^{42}$ and is therefore briefly summarized here. A batch reactor (home-made) (Figure 1) was designed to perform catalyzed photo-reduction of mercury in the liquid samples. The system consisted of a miniaturized quartz reactor ( $7 \mathrm{~mL}$ capacity) sealed up with silicone stoppers (Merck, Darmstadt, Germany). In this work the reactor was irradiated with a medium pressure mercury vapour lamp Heraeus TQ 150 (150W, see Figure 2) (Hanau, Germany) fixed in a water cooled jacket with a fan cooling system (home-made). A hole was made in the stopper so that a $3 \mathrm{~mm}$ diameter microtip of ultrasonic homogenizer could be inserted into the reactor. The microtip made of high purity 
titanium was inserted through the stopper and positioned at the centre of the reactor so that it was immersed $c a .5 \mathrm{~mm}$ into the sample solution.

A $70 \mathrm{~W}, 20 \mathrm{kHz}$ Sonopuls HD 70 ultrasonic homogenizer VC-100 (Bandelin, Germany) was used for separation of mercury vapour from sample solution after UV reduction. The reactor was fitted with gas-liquid separator to eliminate any water vapour that might be transported to the quartz tube (Aula-254) and was connected to a gas supply (Ar) by PTFE capillary tubes.

A Sonopuls HD 70 ultrasonic homogenizer equipped with a $3 \mathrm{~mm}$ titanium microtip was also used in sample preparation step.

A mercury analyser (Model Aula-254, Mercury Instruments, GmbH, Karlsfeld, Germany) with mercury electrodeless low pressure discharge lamp as the radiation source was used for analysis. Peak height absorbance of the transient signal was used for quantification. Instrumental parameters were set up as follows: lamp intensity, 4-20 mA; wavelength, $253.7 \mathrm{~nm}$; spectral bandpass, $0.4 \mathrm{~nm}$; quartz cell temperature, $50{ }^{\circ} \mathrm{C}$. Deuterium lamp background correction was used throughout.

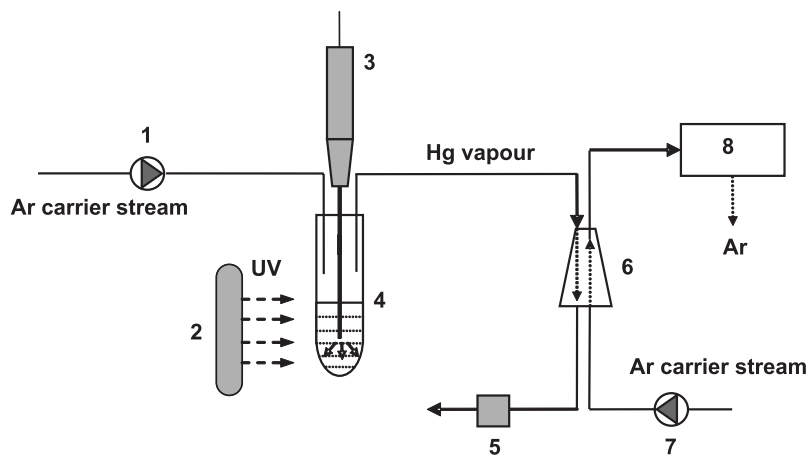

Figure 1. Schematic diagram of catalyzed UV-induced cold vapour generation of mercury coupled to AAS; 1 and 7: mass-flow controller, 2: UV lamp, 3: ultrasonic probe with titanium microtip, 4: sample solution with catalyst and formic acid, 5: peristaltic pump, 6: gas-liquid separator, 8: AULA atomic absorption spectrometer.

During the preparation of nano- $\mathrm{Ag}-\mathrm{TiO}_{2}$ a cylindrical glass photoreactor (Heraeus, Hanau, Germany) of $0.6 \mathrm{~L}$ capacity was used. It consisted of an immersion UV low pressure lamp TNN 15/32 $(15 \mathrm{~W})$ which provided light of wavelength mainly about $254 \mathrm{~nm}$. The lamp operated by utilizing a vertically arranged immersion tube, immersed into the reaction liquid. The reactor was placed on top of a magnetic stirrer for agitation.

\section{Reagents and certified reference materials}

Compressed argon of N55 purity (99.9995\%) (BOC GAZY, Poznań, Poland) was employed in CVAAS system.

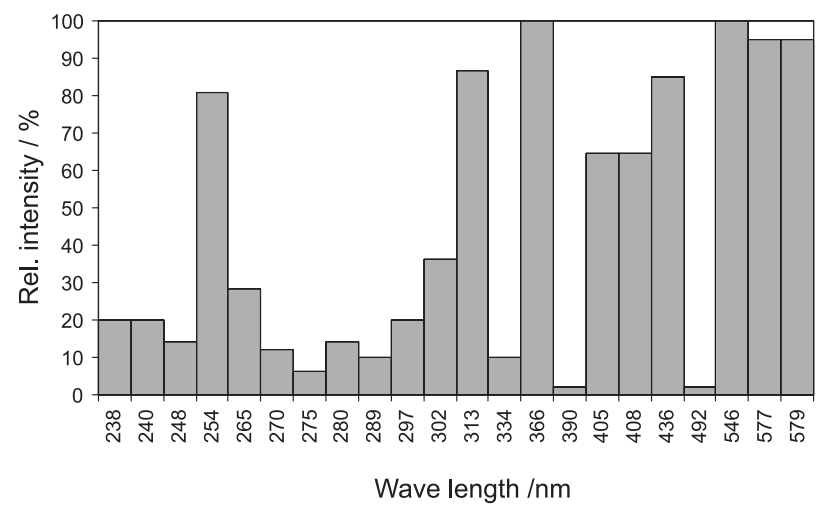

Figure 2. Emission spectrum of the UV lamp Heraeus TQ 150, used for catalyzed photo-reduction of mercury in CVAAS system.

Samples before mercury determination were bubbled with nitrogen 5.0 (99.999\%) (BOC GAZY, Poznań, Poland) to make the suspensions oxygen free. High-purity water, which was sequentially purified by deionization (DEMIWA 5 ROSA, Watek, Czech Republic) and two-stage quartz distillation (Heraeus Bi18, Hanau, Germany), was used throughout this study.

Standard solution of mercury [as $\mathrm{Hg}\left(\mathrm{NO}_{3}\right)_{2}$ ] was prepared from a $1000 \mathrm{mg} \mathrm{L}^{-1} \mathrm{Hg}$ atomic absorption standard (Merck, Darmstadt, Germany) stabilizing with potassium dichromate (5\% m/v, GR, Merck, Darmstadt, Germany). The stock solutions were stored at $4{ }^{\circ} \mathrm{C}$ prior to use. All working standard solutions of mercury were prepared daily to prevent any possible concentration changes, by diluting appropriate aliquots of the stock solution in water.

The $\mathrm{pH}$ of the sample solutions was adjusted with $\mathrm{NaOH}$ (30\%, suprapur) obtained from Merck (Darmstadt, Germany). Formic acid (89-91\%) from Merck (GR, Darmstadt, Germany) was used during sample preparation, as precursor of the reducing species in the UV-induced reduction system and as the organic hole scavenger during mercury reduction and $\mathrm{Ag}-\mathrm{TiO}_{2}$ preparation. In preparation of $\mathrm{Ag}-\mathrm{TiO}_{2}$ silver nitrate (extra pure, Merck, Darmstadt, Germany) was used.

$\mathrm{TiO}_{2}(\mathrm{P} 25$ aeroxide, Degussa, Germany $) \geq 99.5$, spherical particles $(10-30 \mathrm{~nm})$ were used as catalyst, average particle size was approximately $21 \mathrm{~nm}$, specific surface according to BET $50 \pm 15 \mathrm{~m}^{2} \mathrm{~g}^{-1}$ with an anatase:rutile ratio of about 80:20. The size of the band gap was $3.05 \mathrm{eV}$ for rutile and $3.20 \mathrm{eV}$ for anatase. Zinc oxide nanopowder (> 97\%) was obtained from Sigma-Aldrich (Germany), particle size was $<50 \mathrm{~nm}$ (TEM), surface area $>10.8 \mathrm{~m}^{2} \mathrm{~g}^{-1}$.

Accuracy verification of the catalyzed photo-reduction of mercury described in this work was performed using certified reference materials. The following materials were chosen: DOLT-2 (dogfish liver) and TORT-2 (lobster hepatopancreas) from National Research Council of Canada 
(Ottawa, Canada) and IAEA-086 (human hair), IAEA-336 (lichen) from International Atomic Energy Agency (Austria). The certified reference values were available for mercury for assessment of the method accuracy. All solid reference materials were used as bottled, without further grinding and sieving.

\section{Preparation of nano-Ag- $\mathrm{TiO}_{2}$}

The $\mathrm{Ag}-\mathrm{TiO}_{2}$ particles were prepared by photo-reducing $\mathrm{Ag}(\mathrm{I})$ ions (from $\mathrm{AgNO}_{3}$ ) to $\mathrm{Ag}$ metal on the $\mathrm{TiO}_{2}$ surface. ${ }^{38}$ An amount of $2 \mathrm{~g}$ of $\mathrm{TiO}_{2}$ was added into $0.5 \mathrm{~L}$ of deionised water in the photoreactor and then irradiated for $5 \mathrm{~min}$ to remove any impurities that might be present on the $\mathrm{TiO}_{2}$ surface. Aliquots of various amounts of $\mathrm{Ag}(\mathrm{I})$ ions, prepared by dissolving silver nitrate in deionised water, were added into the suspension of $\mathrm{TiO}_{2}$ such that the ions concentration was of $0.2,0.4,0.6$ and $1.2 \%$ in relation to $\mathrm{TiO}_{2}$. In this paper, the modified catalyst will be denoted as $\mathrm{x} \% \mathrm{Ag}-\mathrm{TiO}_{2}$, where $x$ indicates the mass percentage of starting $\mathrm{Ag}$ in theoretical products. $\mathrm{Ag}-\mathrm{TiO}_{2}$ composites with various $\mathrm{Ag}$ loadings (0.2-1.2\%) were obtained.

Formic acid (89-91\%) was used as the organic hole scavenger and its concentration was adjusted to $0.025 \mathrm{~mol} \mathrm{~L}^{-1}$ as carbon. The suspension was adjusted to $\mathrm{pH} 3.5$ by sodium hydroxide (30\%) and then irradiated for 40 min with continuous nitrogen purging. The suspension was then filtered, washed, dried and hand-ground to obtain the brown $\mathrm{Ag}$-deposited $\mathrm{TiO}_{2}$ particles.

\section{Decomposition technique}

The decomposition technique was detailed in previous work $^{43}$ and is therefore briefly summarized here. Nominal $300 \mathrm{mg}$ sub-samples of reference material were weighed into $30 \mathrm{~mL}$ pre-cleaned polypropylene screw-capped cups and $20 \mathrm{~mL}$ of $c a .90 \% \mathrm{~m} / \mathrm{v}$ formic acid was added. Once the 5 min the reaction of the sample with the $\mathrm{HCOOH}$ was completed, suspensions were pretreated by sonication at $50 \mathrm{~W}$ ultrasonic probe power for $5 \mathrm{~min}$. Before further analysis this solution was appropriately diluted depending on the concentration level of the mercury.

\section{Mercury determination}

The photocatalyst powder $\left(\mathrm{TiO}_{2}, \mathrm{Ag}-\mathrm{TiO}_{2}\right.$ or $\left.\mathrm{ZnO}\right)$ was mixed with water and an ultrasonic bath was used to disperse the catalyst's particles homogeneously before use. For mercury determination, appropriate volume of catalyst suspension, $0.5 \mathrm{~mol} \mathrm{~L}^{-1}$ formic acid and a volume ranging from 0.5 to $1.6 \mathrm{~mL}$ of the solubilized sample were made up to volume in a $10 \mathrm{~mL}$ calibrated dark flask with water. The $\mathrm{pH}$ of the suspension was adjusted and controlled using sodium hydroxide. Prior to mercury determination, the suspension was stirred for $1 \mathrm{~min}$ to establish adsorption equilibrium conditions with nitrogen purging $\left(0.2 \mathrm{~L} \mathrm{~min}^{-1}\right.$ in $\left.30 \mathrm{~s}\right)$.

A quantity of $1 \mathrm{~mL}$ of the solution was placed in the reactor for UV-induced vapour generation. Once the $3 \mathrm{~mm}$ diameter microtip was immersed into the solution at a depth of $c a .5 \mathrm{~mm}$ and the sample was sequentially subjected to $20 \mathrm{~s}$ of UV irradiation and $5 \mathrm{~s}$ of ultrasounds irradiation. The mercury vapour was transferred to the quartz cell by an Ar stream $\left(0.125 \mathrm{~L} \mathrm{~min}^{-1}\right)$. Peak height absorbance was taken for quantification.

\section{Results and Discussion}

Effect of oxygen on the catalyzed photo-reduction of mercury

To investigate the effect of oxygen on the photoreduction of $\mathrm{Hg}$ (II) using $\mathrm{TiO}_{2}$, intensity of absorbance was measured in two different conditions for air-equilibrated and nitrogen-purged suspensions (by $\mathrm{N}_{2}$ stream $0.2 \mathrm{~L} \mathrm{~min}^{-1}$ in $30 \mathrm{~s})$. The catalyst $\left(2 \mathrm{~g} \mathrm{~L}^{-1}\right)$ was added to solutions ( $3 \mu \mathrm{g} \mathrm{L} \mathrm{L}^{-1} \mathrm{Hg}$ (II) (DOLT-2)) at $\mathrm{pH} 3.5$ and irradiated for $20 \mathrm{~s}$. It was found that in the absence of $\mathrm{O}_{2}$, analytical signal was about $20 \%$ higher compared to air-equilibrated suspension.

In air-equilibrated sample oxygen competes with $\mathrm{Hg}(\mathrm{II})$ ions for the photogenerated electrons in the airequilibrated suspension to produce $\mathrm{O}_{2}{ }^{--}$radicals and these may act as electron-hole recombination centres, the lower intensity of absorbance of mercury is obtained. This is obvious because the rate constant for oxygen reaction with electron ${ }^{44}\left(\mathrm{O}_{2}+\mathrm{e}^{-}{ }_{\text {aq }} \rightarrow \mathrm{O}_{2}^{--}, \mathrm{k}=1.9 \times 10^{10} \mathrm{~L} \mathrm{~mol}^{-1} \mathrm{~s}^{-1}\right)$ is slightly higher than $\mathrm{Hg}(\mathrm{II})$ reaction ${ }^{44}\left(\mathrm{Hg}(\mathrm{II})+\mathrm{e}^{-}{ }_{\text {aq }} \rightarrow \mathrm{Hg}(\mathrm{I})\right.$, $\left.\mathrm{k}=7.1 \times 10^{9} \mathrm{~L} \mathrm{~mol}^{-1} \mathrm{~s}^{-1}\right)$.

Due to the absence of dissolved oxygen in sample solution a higher reduction rate of mercury can be achieved. The results are in agreement with that reported in literature ${ }^{37,44,45}$ and it must be emphasized that all experiments were conducted in nitrogen-saturated samples.

\section{Optimization of the catalyzed photo-reduction systems}

The chemical and physical variables of the catalyzed photo-induced reduction system were optimized to achieve the best analytical performance by investigating each variable in turn with all other variables kept constant.

In order to investigate the catalyzed reduction of mercury, parameters included type of catalyst, its concentration in the analyzed sample solution, $\mathrm{pH}$ value, 
formic acid concentration and ultraviolet irradiation time have been optimized. All optimization studies were performed with certified reference material - DOLT 2 with mercury concentration $3 \mu \mathrm{g} \mathrm{L} \mathrm{L}^{-1}$ using peak height measurements. This material was chosen as an excellent matrix to demonstrate the feasibility of the criteria applied in this study to determine optimal experimental conditions.

\section{Catalyzed photo-reduction of mercury by nano- $\mathrm{TiO}_{2}$}

\section{Selection of formic acid concentration, $\mathrm{pH}$ and UV irradiation} time

In literature ${ }^{26,32,34}$ was demonstrated that the reduction of $\mathrm{Hg}$ (II) could be achieved with formic acid in the presence of UV irradiation. Unfortunately, in the cited studies, the reduction efficiency of mercury in the presence of formic acid by the photo-induced cold vapour generation system was not significantly improved by use of nano- $\mathrm{TiO}_{2}$. The purpose of this study was to analyse these reports with using a UV lamp of high power and miniaturized quartz reactor positioned very close to the UV lamp. In order to increase reduction efficiency and for fast $\mathrm{Hg}$ removal from the sample solution to the gas phase, after UV reduction, ultrasound was used..$^{42}$ To decrease the effect of dissolved oxygen on the reduction, the samples prior to mercury determination were bubbled with nitrogen to make the suspensions oxygen free.

It is well known that the efficiency of photo-catalyzed reactions is determined by the interfacial electron-transfer rate and the recombination lifetime of the photo-generated holes and electrons. To enhance reduction of mercury, the most common way is to increase the recombination lifetime of holes and electrons. Therefore, in the process of photo-catalytic reduction of metal ions, filling the valence band holes by the electrons of the organic compound may accelerate the reaction. In the absence of organic species, in liquid samples, the photo-generated holes would have to be consumed by water. ${ }^{44}$

In order to complete the hole transfer, formic acid was selected as the hole scavenger in experiments. The acid is a small molecule, which is easily adsorbed onto $\mathrm{TiO}_{2}$. It easily forms reducing radicals and gases in the liquid medium upon ultraviolet irradiation and could behave as precursor for the reducing species. In addition, provides an appropriate medium for the sample preparation, especially with the participation of ultrasound. ${ }^{31,43,46}$ It functioned also as the acidic medium for catalyzed reactions at the same time, and this led to the simplest possible catalyzed UV-induced CVG system. Other common inorganic acids such as nitric acid and sulphuric acid were not tested in this work because of their oxidising nature which could result in lower analytical signals.
Figure 3a illustrates that the efficiency of mercury catalyzed vapour photo-generation depended on the formic acid concentration. It was optimized in range of $0-2 \mathrm{~mol} \mathrm{~L}^{-1}$. Increasing concentration of formic acid in $\mathrm{Hg}$ (II) solution from 0 to $0.5 \mathrm{~mol} \mathrm{~L}^{-1}$ increased the intensity of absorbance. The optimal value of the concentration of formic acid for mercury reduction was found to be $0.5 \mathrm{~mol} \mathrm{~L}^{-1}$, which indicates that the re-oxidation of $\mathrm{Hg}(0)$ occurs easily under strongly acidic conditions ${ }^{44}$ Formic acid generated radicals that reduced $\mathrm{Hg}(\mathrm{II})$ to $\mathrm{Hg}(0)$ under the UV irradiation and acted as an efficient hole scavenger during the reaction. In comparison with previous studies, ${ }^{42}$ catalyzed reduction by nano- $\mathrm{TiO}_{2}$ requires a slightly lower concentration of formic acid.

Figure $3 \mathrm{~b}$ shows the effect of the ultraviolet irradiation time on absorbance. The ultraviolet irradiation time for efficient catalyzed reduction of mercury was optimized in range between 0 and $30 \mathrm{~s}$. Very low signal can be detected without the UV irradiation. It may be due to exposure of the sample to visible light in the laboratory. ${ }^{26}$ Increasing absorbance was observed on increasing ultraviolet irradiation time and absorbance slightly decreased for time larger than $20 \mathrm{~s}$. This could be due to overheating of the sample solution, and losses of mercury. The time of ultraviolet irradiation equal to $20 \mathrm{~s}$ was chosen for further study.

It can be seen from Figure $3 \mathrm{c}$ that the $\mathrm{Hg}$ (II) photoreduction in the presence of nano- $\mathrm{TiO}_{2}$ is a function of different solution $\mathrm{pH}$ values. The sample $\mathrm{pH}$ was investigated in range between 1.5 and 4.5. Decreasing the $\mathrm{pH}$ decreased the intensity of absorbance. The optimal value of $\mathrm{pH}$ of sample solution was found to be 3.5. The $\mathrm{pH}$ of the sample solutions was adjusted with $\mathrm{NaOH}$, after the addition of the catalyst. In literature for comparison, catalyzed photo-reduction of mercury has been reported at $\mathrm{pH} 4^{37,44}$ and the degradation of wastewaters (dyes) in the presence of $\mathrm{TiO}_{2}$ with the additional effect of ultrasound, as low as $1-3 .{ }^{47}$

The results obtained are consistent with those obtained by Wang et al. ${ }^{44}$ The surface properties of the $\mathrm{TiO}_{2}$ semiconductor are strongly affected by solution $\mathrm{pH}$ which changes the potential of conduction band electrons. Under strongly acidic condition the photo-oxidation of $\mathrm{Hg}(0)$ is possible, which inhibits the overall rate of $\mathrm{Hg}$ (II) reduction by photo-generated holes. It can be explained by the effect of solution $\mathrm{pH}$ on the potential of conduction band electrons and the surface properties of the $\mathrm{TiO}_{2}$ semiconductor. ${ }^{44}$

\section{Influence of nano- $\mathrm{TiO}_{2}$ particles}

As shown in Figure 3d the intensity of absorbance increased when $\mathrm{TiO}_{2}$ was added in the reaction. Electrons 

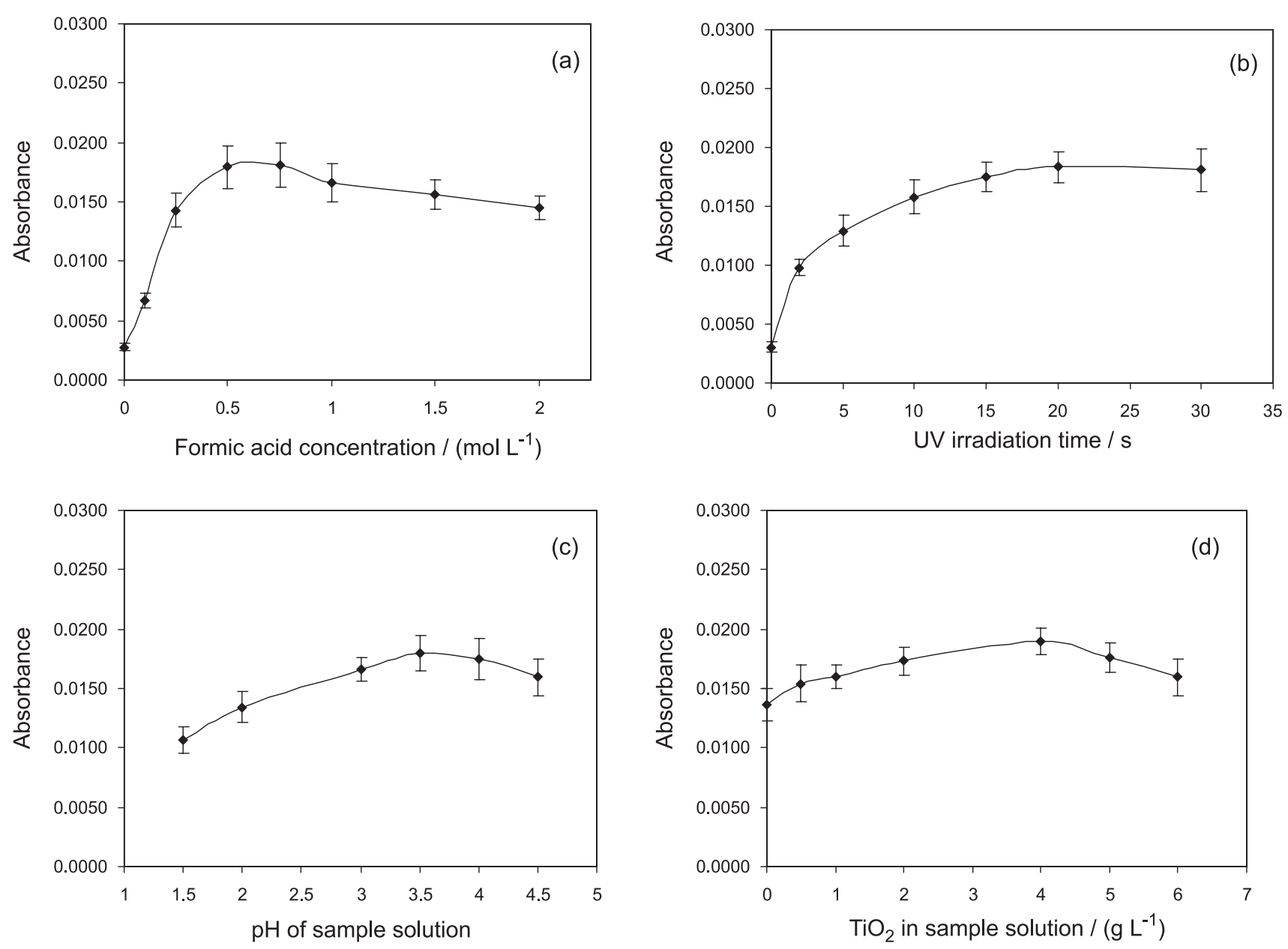

Figure 3. Effect of the selected parameters on the analytical signal of mercury during the photo-induced cold vapour generation in the presence of nano- $\mathrm{TiO}_{2}$ : (a) formic acid concentration, (b) ultraviolet irradiation time, (c) sample $\mathrm{pH}$, (d) concentration of $\mathrm{TiO}_{2} ; 3 \mu \mathrm{g} \mathrm{L}{ }^{-1} \mathrm{Hg}$ DOLT-2 (error bars represent the standard deviation for $\mathrm{n}=3$ ).

and holes were generated on the surface of catalyst and mercury was reduced by the electrons on the surface of nano- $\mathrm{TiO}_{2}$ (which has very high surface area). When the concentration of $\mathrm{TiO}_{2}$ increased, the absorbance of mercury was enhanced. However, when the $\mathrm{TiO}_{2}$ dose exceeded $4 \mathrm{~g} \mathrm{~L}^{-1}$ the analytical signal decreased. It was probably caused by lower light penetration through the sample- $\mathrm{TiO}_{2}$ suspension.

Wang's et al. ${ }^{47}$ results indicate the ultrasonic degradation effects of substances present in the solution are more obvious in the presence of rutile $\mathrm{TiO}_{2}$ than in the presence of anatase $\mathrm{TiO}_{2}$. These results are just in opposition to photocatalytic degradation in the presence of $\mathrm{TiO}_{2}$. The photocatalytic activity of anatase is very obvious and the rutile has little activity during usual photocatalytic reaction. It can be concluded that rutile presents in $\mathrm{TiO}_{2}$ (at 20\%) interacts with the ultrasound which allows obtaining higher analytical signals compared with the signals obtained without catalyst. The optimized nano- $\mathrm{TiO}_{2}$ concentration was $4 \mathrm{~g} \mathrm{~L}^{-1}$. Using a catalyst made it possible to increase the analytical signal by about $25 \%$ with the relative standard deviation about $6 \%$.

\section{Catalyzed photo-reduction of mercury by nano- $\mathrm{Ag}-\mathrm{TiO}_{2}$}

\section{Effect of $\mathrm{TiO}_{2}$ modification}

It is realized that depositing metal islands on the surface of $\mathrm{TiO}_{2}$ improves photo-degradation efficiency of semiconductor. Unfortunately, the influence of noble metals deposited on the surface of $\mathrm{TiO}_{2}$ on the efficiency of photo-reduction for cold vapour generation systems has rarely been investigated until now.

To evaluate the photoactivity of $\mathrm{Ag}-\mathrm{TiO}_{2}$ composites, unmodified $\mathrm{TiO}_{2}$, a commercial photocatalyst with high photoactivity, was used to catalyze reduction of mercury under the same conditions.

In photo-catalysis, the addition of noble metals to a semiconductor can change the photocatalytic process by changing the semiconductor surface properties. ${ }^{48}$ The metal can enhance the yield of a particular product or the rate of the 
photocatalytic reaction. During the study, the photocatalytic activity of $\mathrm{Ag}-\mathrm{TiO}_{2}$ varied with the different content of $\mathrm{Ag}$. Figure 4a shows the effect of silver content on the photoreduction of mercury. It can be seen that the photocatalytic activity of $\mathrm{TiO}_{2}$ particles can be improved by depositing silver. The reduction rate increases significantly when the silver deposits at a low content. The photocatalytic activity is even higher than that of unmodified $\mathrm{TiO}_{2}$. The mercury absorbance increases continuously as the silver content is increased up to a content level of $0.6 \%$ and then decreases with further increase of the content of $\mathrm{Ag}$ in the $\mathrm{Ag}-\mathrm{TiO}_{2}$. Thus, the optimum Ag content is approximately $0.6 \%$.

These results demonstrate the incorporation of noble metal onto the $\mathrm{TiO}_{2}$ surface changes the rate of electron transfer during catalyzed cold vapour generation. The transfer is facilitated from a material of lower work function to one that has a higher work function. For the $\mathrm{Ag}-\mathrm{TiO}_{2}$, the work function of $\mathrm{Ag}(4.6 \mathrm{eV})$ is greater than that of
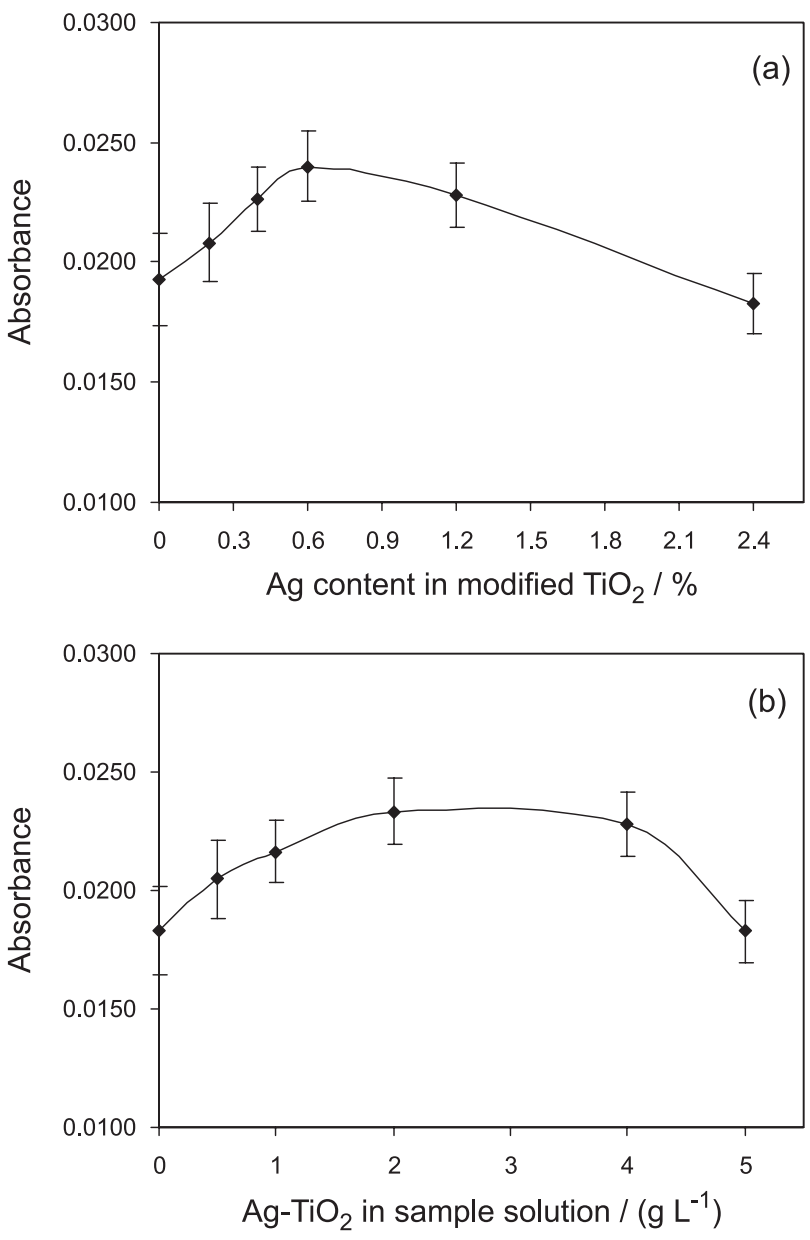

Figure 4. Effect of the selected parameters on the analytical signal of mercury during the photo-induced cold vapour generation in the presence of nano-Ag- $\mathrm{TiO}_{2}$ : (a) Ag content in nano-Ag- $\mathrm{TiO}_{2}$, (b) concentration of nano-Ag- $\mathrm{TiO}_{2}$ in sample solution; $0.5 \mathrm{~mol} \mathrm{~L}^{-1} \mathrm{HCOOH}, \mathrm{pH}=3.5$, UV time $20 \mathrm{~s}, 3 \mu \mathrm{g} \mathrm{L}^{-1} \mathrm{Hg}$ DOLT-2 (error bars represent the standard deviation for $\mathrm{n}=3$ ).
$\mathrm{TiO}_{2}(4.2 \mathrm{eV})$ while that of metal should be greater than that of Ag. ${ }^{38,49}$ Than electrons can hence be transferred from $\mathrm{TiO}_{2}$ to $\mathrm{Ag}$ and then to metal as the energy barrier for electron transfer from $\mathrm{Ag}$ to $\mathrm{TiO}_{2}$ or from metal to $\mathrm{Ag}$ is higher than that of the opposite. Many studies involving surface modification of $\mathrm{TiO}_{2}$ by metal loading such as $\mathrm{Au}^{50}$ or $\mathrm{Ag}^{51}$ have explained the transfer of electron with this theory. In the presented experiment work function for mercury is $4.5 \mathrm{eV},{ }^{49}$ slightly lower than for silver. Therefore, it is difficult to decide about mechanism of the mercury reduction which is responsible for the higher analytical signals when $\mathrm{Ag}-\mathrm{TiO}_{2}$ is used. In the analyzed samples, mercury is present in the very complex matrix, which may change the terms of the reduction. Additionally the photo-induced cold vapour generation system is based on interaction ultraviolet and ultrasound irradiation, which also affect the course of photochemical reactions.

However, the results show that the presence of a proper content of silver can reduce electron-hole recombination in the cold vapour generation system and increase the photocatalytic activity of $\mathrm{TiO}_{2}$.

\section{Influence of nano-Ag- $\mathrm{TiO}_{2}$ particles}

In order to investigate the optimum concentration of nano- $\mathrm{Ag}-\mathrm{TiO}_{2}$ on the reduction of mercury, catalyzed cold vapour generation was conducted by varying the concentration of catalyst from 0 to $5.0 \mathrm{~g} \mathrm{~L}^{-1}$ (Figure 4b). As can be seen, the optimal concentration of nano- $\mathrm{Ag}-\mathrm{TiO}_{2}$ was about $2.0 \mathrm{~g} \mathrm{~L}^{-1}$. A low concentration of catalyst resulted in low reduction efficiency, because there were not an adequate number of catalytic particles to positively affect the reaction. An improperly high concentration of $\mathrm{Ag}-\mathrm{TiO}_{2}$ decreased the absorbance of mercury. Nano- $\mathrm{Ag}-\mathrm{TiO}_{2}$ as catalyst in cold vapour generation system contributed to increase of the analytical signal by about $45 \%$ with the relative standard deviation about $6 \%$ in comparison to sample without any catalyst. Comparing the analytical signals for samples with unmodified $\mathrm{TiO}_{2}$ and $\mathrm{Ag}-\mathrm{TiO}_{2}$ around $15 \%$ increase in the absorbance was observed.

\section{Catalyzed photo-reduction of mercury by $\mathrm{ZnO}$}

Although $\mathrm{TiO}_{2}$ is universally recognized as the most photoactive catalyst, $\mathrm{ZnO}$ is a suitable alternative to $\mathrm{TiO}_{2}$ as it has similar band gap energy $(3.2 \mathrm{eV})$. Despite the similarities $\left(\mathrm{TiO}_{2}\right.$ and $\left.\mathrm{ZnO}\right)$, the different nature of the catalyst $(\mathrm{ZnO})$ required optimization of main parameters. The major parameters that influence the rate and conversion of $\mathrm{Hg}(\mathrm{II})$ to $\mathrm{Hg}(0)$ in the presence of $\mathrm{ZnO}$ are the concentration of the semiconductor catalyst, the $\mathrm{pH}$ of the sample solution, the time of the UV radiation and the 
concentration of the hole scavenger (formic acid). As in the case of $\mathrm{TiO}_{2}$ the effects of the parameters were studied over selected ranges of their values.

The $\mathrm{pH}$ of the solution is an important parameter in photocatalytic processes. A few experiments at different $\mathrm{pH}$ values were conducted. The corresponding absorbance for reduction of $\mathrm{Hg}$ (II) in the presence of $\mathrm{ZnO}$ is presented in Figure 5a. It appears that the absorbance is maximum at a $\mathrm{pH} 4.5$ but decreases rapidly with increasing $\mathrm{pH}$. The $\mathrm{pH}$ of the sample solutions was adjusted with $\mathrm{NaOH}$, after the addition of the catalyst. The range of $\mathrm{pH}$ for the photocatalytic reduction of mercury using $\mathrm{ZnO}$ is rather limited. The catalyst dissolves at a low $\mathrm{pH}$ and a high $\mathrm{pH}$ is detrimental to both the catalyst and the species generated in course of irradiation of the catalyst. This observation has been reported in literature. ${ }^{52-54}$ It should be mentioned that $\mathrm{TiO}_{2}$ is more resistant to lower solution $\mathrm{pH}$. In presented work optimum for cold vapour generation in presence of $\mathrm{TiO}_{2}$ was 3.5.
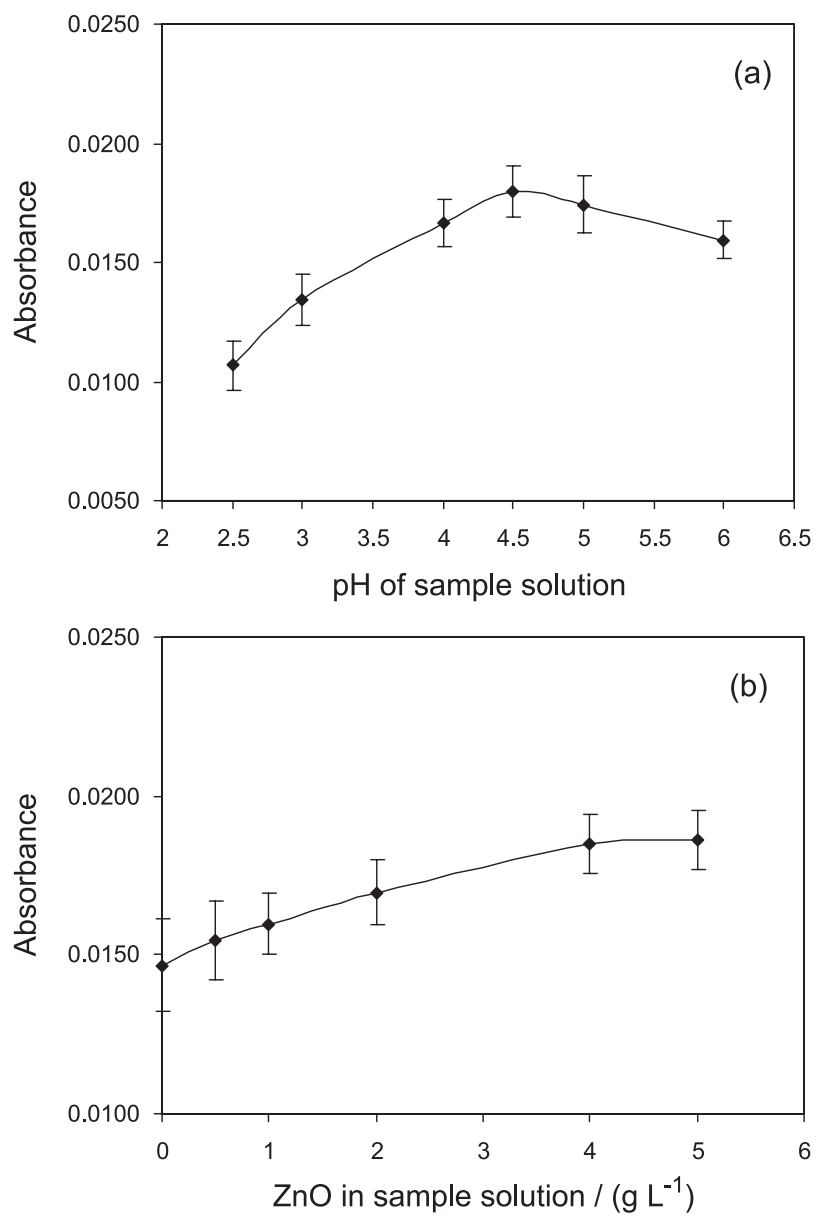

Figure 5. Effect of the selected parameters on the analytical signal of mercury during the photo-induced cold vapour generation in the presence of $\mathrm{ZnO}$ : (a) sample $\mathrm{pH}$, (b) concentration of $\mathrm{ZnO}$ in sample solution; $0.5 \mathrm{~mol} \mathrm{~L}{ }^{-1} \mathrm{HCOOH}, \mathrm{pH}=3.5$, UV time $20 \mathrm{~s}, 3 \mu \mathrm{g} \mathrm{L}{ }^{-1} \mathrm{Hg}$ DOLT-2 (error bars represent the standard deviation for $\mathrm{n}=3$ ).
The enhancing role of a sacrificial (additional) electron donor for photocatalytic reduction of $\mathrm{Hg}$ (II) has been widely commented in the literature. The addition of a hole scavenger (organic compound) is necessary to enhance the reduction efficiency and to exploit the potential of the catalyzed photo-reduction fully. As indicated above in the case of $\mathrm{TiO}_{2}$, formic acid has been used as the hole scavenger. Also in the case of $\mathrm{ZnO}$, for the same purpose, formic acid was chosen. It is cheaper and less toxic (particularly the case of methanol) than other agents reported in the literature and also because it has been used in sample preparation step. The intensity of absorbance increased with the concentration of acid and a plateau appeared when its concentration was around $0.5 \mathrm{~mol} \mathrm{\textrm {L } ^ { - 1 }}$. In experiments with $\mathrm{ZnO}$, a formic acid concentration of $0.5 \mathrm{~mol} \mathrm{~L}^{-1}$ was chosen. The ultraviolet irradiation time for efficient catalyzed reduction of mercury by $\mathrm{ZnO}$ was checked in range between 0 and $30 \mathrm{~s}$. Increasing absorbance was observed on increasing ultraviolet irradiation time. A plateau was reached from times longer than $20 \mathrm{~s}$ and absorbance slightly decreased for time larger than $25 \mathrm{~s}$. As in the case of $\mathrm{TiO}_{2}$ this could be due to overheating of the sample solution, and losses of mercury. The optimal ultraviolet irradiation time of $20 \mathrm{~s}$ was established. As can be seen $\mathrm{TiO}_{2}$ and $\mathrm{ZnO}$ required the same formic acid concentration in sample solution $\left(0.5 \mathrm{~mol} \mathrm{~L}^{-1}\right)$ just as the same ultraviolet irradiation time (20 s).

To investigate the optimum concentration of $\mathrm{ZnO}$ on the reduction of mercury, catalyzed cold vapour generation was conducted by varying the concentration of catalyst from 0 to $5.0 \mathrm{~g} \mathrm{~L}^{-1}$ (Figure 5b). Reduction of mercury was found to increase with the increase in $\mathrm{ZnO}$ concentration from 0.5 to $4 \mathrm{~g} \mathrm{~L}^{-1}$ of catalyst. Higher concentrations of catalyst enhance the interception of UV radiation by the particles and enable to obtain higher analytical signals; the optimal concentration of $\mathrm{ZnO}$ was about $4.0 \mathrm{~g} \mathrm{~L}^{-1}$.

$\mathrm{ZnO}$ as catalyst in cold vapour generation system contributed to increase of the analytical signal by about $14 \%$ with the relative standard deviation about $5 \%$ in comparison to sample without any catalyst. Comparing the analytical signals for samples with unmodified $\mathrm{TiO}_{2}$, $\mathrm{Ag}-\mathrm{TiO}_{2}$ and $\mathrm{ZnO}$ it should be noted that the last catalyst was characterized by the lowest photocatalytic efficiency.

\section{Comparison of optimized procedures for the catalyzed reduction of mercury}

It is difficult to refer the presented results to the literature. There are only few papers on catalyzed cold vapour generation for mercury determination in analytical samples. The most commonly used catalyst in reduction of 
mercury is $\mathrm{TiO}_{2} \cdot{ }^{26,32} \mathrm{The} \mathrm{Ag}-\mathrm{TiO}_{2}$ and $\mathrm{ZnO}$ photocatalysts have been used by a few other researchers but only for photolysis of water containing selenium compounds ${ }^{38}$ or wastewater. ${ }^{53,55}$

In this paper the photocatalytic activities of $\mathrm{TiO}_{2}$, $\mathrm{Ag}-\mathrm{TiO}_{2}$ and $\mathrm{ZnO}$ for reduction of mercury was compared. In optimized parameters the highest activity was obtained for modified $\mathrm{TiO}_{2}$. Nano-Ag $-\mathrm{TiO}_{2}$ as catalyst in cold vapour generation system contributed to increase of the analytical signal by about $45 \%$ in comparison to sample without any catalyst. Activities of unmodified $\mathrm{TiO}_{2}$ and $\mathrm{ZnO}$ were lower ( $22 \%$ and $14 \%$ increase in analytical signals respectively). Table 1 summarizes all optimized experimental conditions used for the determination of mercury by catalyzed UV-induced reduction CVAAS.

Due to the best results for nano- $\mathrm{Ag}-\mathrm{TiO}_{2}$, the catalyst was used for determination of mercury in selected certified reference materials.

\section{Accuracy verification and figures of merit}

Analytical characteristics of the method were established under optimal conditions for the catalyzed by nano- $\mathrm{Ag}-\mathrm{TiO}_{2}$ photo-induced cold vapour generation of mercury coupled to AAS. For calibration purpose mercury standard $\mathrm{Hg}\left(\mathrm{NO}_{3}\right)_{2}$ was chosen. It ionises in solution as $\mathrm{Hg}^{2+}$ and $\mathrm{NO}_{3}{ }^{-}$ions and hence it is more prone to reduce. In order to decrease the effect of dissolved oxygen on the reduction, the samples before mercury determination were bubbled with nitrogen to make the suspensions oxygen free. Under the optimized experimental conditions (Table 1), a calibration curve was constructed with a series of $\mathrm{Hg}$ (II) standards (1-25 $\left.\mu \mathrm{g} \mathrm{L}^{-1}\right)$ using replicate measurements $(n=5)$ of mercury standards giving a linear response with the regression coefficient was $r^{2}=0.9997$.

The limits of detection and quantification (defined as the concentration equivalent to three and ten, respectively times the standard deviation of the blank $(\mathrm{n}=10))$ were
Table 1. Optimized experimental conditions for catalyzed UV-induced cold vapour generation of mercury coupled to AAS (parameters for sample preparation are also presented)

\begin{tabular}{|c|c|}
\hline \multicolumn{2}{|c|}{ Sample ultrasound - solubilization } \\
\hline Sample mass / mg & ca. 300 \\
\hline Reagent & $\mathrm{HCOOH}$ \\
\hline Reagent concentration / \% & ca. 90 \\
\hline Final volume / $\mathrm{mL}$ & 20 \\
\hline US power / W & 50 \\
\hline Sonication time / $\mathrm{min}$ & 5 \\
\hline \multicolumn{2}{|c|}{ Catalyzed UV-induced cold vapour generation } \\
\hline $\begin{array}{l}\text { Catalyst : concentration in } \\
\text { sample solution } /\left(\mathrm{g} \mathrm{L}^{-1}\right)\end{array}$ & $\begin{array}{l}\mathrm{TiO}_{2}: 4 \\
\mathrm{Ag}-\mathrm{TiO}_{2}: 2 \\
\mathrm{ZnO}: 4\end{array}$ \\
\hline Ultraviolet time / s & 20 \\
\hline $\begin{array}{l}\text { Formic acid concentration / } \\
\left(\mathrm{mol} \mathrm{L}^{-1}\right)\end{array}$ & 0.5 \\
\hline Microtip diameter / mm & 3 \\
\hline Sonication time / s & 5 \\
\hline Sample volume / $\mathrm{mL}$ & 1 \\
\hline Ar flow / $\left(\mathrm{L} \mathrm{min}^{-1}\right)$ & 0.125 \\
\hline \multicolumn{2}{|c|}{ Detection } \\
\hline AAS & $\begin{array}{l}\text { Aula- } 254 \text { mercury instruments; } \\
\text { mercury EDL, } 10 \mathrm{~mA} \text {; } \\
\text { wavelength, } 253.7 \mathrm{~nm} \text {; } \\
\text { spectral bandpass, } 0.4 \mathrm{~nm} \text {; } \\
\text { quartz cell temperature, } 50^{\circ} \mathrm{C} \text {; } \\
\text { measurement mode, peak height }\end{array}$ \\
\hline
\end{tabular}

$0.13 \mu \mathrm{g} \mathrm{L} \mathrm{L}^{-1}$ and $0.44 \mu \mathrm{g} \mathrm{L} \mathrm{L}^{-1}$, respectively. The limits of detection and quantification of total $\mathrm{Hg}$ in the samples were 9 and $29 \mathrm{ng} \mathrm{g}^{-1}$, respectively. Obtained limit of detection was compared with those reported for the use of photochemical vapour generation with AAS detection (Table 2).

To evaluate the applicability of the proposed method of mercury determination in analysis of analytical samples four certified reference materials (dogfish liver,

Table 2. Comparison of mercury determination by UV-induced cold vapour generation with absorption detection

\begin{tabular}{|c|c|c|c|c|c|}
\hline CVG system & $\begin{array}{l}\text { Organic compound } \\
\text { (medium for reduction) }\end{array}$ & $\begin{array}{l}\text { Sample preparation } \\
\text { step }\end{array}$ & Sample & $\begin{array}{l}\text { Limit of detection / } \\
\qquad\left(\mu \mathrm{g} \mathrm{L}^{-1}\right)\end{array}$ & Ref. \\
\hline $\mathrm{Ag}-\mathrm{TiO}_{2}-\mathrm{UV}-\mathrm{CVG}$ AAS & Formic acid & $\begin{array}{l}\text { US }^{\mathrm{a}} \text {-assisted } \\
\text { solubilisation in } \\
\text { formic acid }\end{array}$ & $\begin{array}{c}\text { Biological / } \\
\text { environmental samples }\end{array}$ & 0.13 & This work \\
\hline UV-CVG AAS & Formic acid & $\begin{array}{l}\text { US }^{\mathrm{a}} \text {-assisted } \\
\text { solubilisation in } \\
\text { formic acid }\end{array}$ & Biological tissues & 0.1 & 31 \\
\hline UV-CVG AAS & Acetic acid & $\begin{array}{l}\text { Solubilisation } \\
\text { in } \mathrm{TMAH}^{\mathrm{b}}\end{array}$ & Dogfish liver & 2.1 & 27 \\
\hline
\end{tabular}

${ }^{\mathrm{a} u l t r a s o u n d ;}{ }^{\mathrm{b}}$ tetramethylamonium hydroxide. 
Table 3. Accuracy verification of the UV-induced CVAAS method catalyzed by nano-Ag-TiO ${ }_{2}$ for mercury determination in selected certified reference materials in optimized conditions. Recovery and relative standard deviation (RSD) values are also shown. Obtained values: average value \pm standard deviation for $n=3$

\begin{tabular}{|c|c|c|c|c|}
\hline \multirow{2}{*}{ Reference material code } & \multicolumn{3}{|c|}{ Determined } & \multirow{2}{*}{$\frac{\text { Certified }}{\mathrm{Hg} \text { total } /\left(\mu \mathrm{g} \mathrm{g}^{-1}\right)}$} \\
\hline & Hg total $/\left(\mu g^{-1}\right)$ & Recovery / \% & RSD / \% & \\
\hline IAEA-336 & $0.19 \pm 0.02$ & 95 & 11 & $0.20 \pm 0.04$ \\
\hline TORT-2 & $0.26 \pm 0.02$ & 96 & 7 & $0.27 \pm 0.06$ \\
\hline IAEA-086 & $0.559 \pm 0.031$ & 99 & 6 & $0.573 \pm 0.039$ \\
\hline DOLT-2 & $1.98 \pm 0.09$ & 99 & 6 & $1.99 \pm 0.10$ \\
\hline
\end{tabular}

lobster tissue, human hair and lichen) were solubilized in formic acid and analyzed. Table 3 shows the mercury concentrations found in reference materials employing the catalyzed by nano-Ag- $\mathrm{TiO}_{2}$ UV-induced CVAAS under the optimized conditions. The results were obtained by standard addition technique. It can be seen from Table 3 that recovery for four reference materials containing 0.20 -

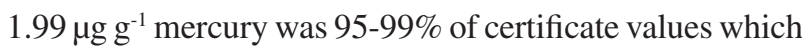
is considered satisfactory for the low concentration levels of mercury. The results were in good agreement with the $t$-test at a 95\% confidence level of the certified values in the investigated reference materials. The precision expressed as relative standard deviation (RSD, \%) was equal to or better than $11 \%$ for the samples.

\section{Conclusions}

To summarise, a new method has been presented for the mercury determination, based on the catalyzed UV-induced reduction of the analyte with formic acid and AAS detection of the generated mercury vapour. The results obtained in this study showed that the proposed method is appropriate for the determination of mercury for the low concentration levels of analyte in biological and environmental samples.

The study has shown that the presence of oxygen in the sample suspension plays an important role in the UV-induced reduction of mercury. The oxygen molecule acts as an electron acceptor and minimizes the chance of electron-hole pair recombination. Therefore determination of mercury was possible for samples bubbled with nitrogen to make the suspensions oxygen free.

It can also be concluded that rutile present in $\mathrm{TiO}_{2}$ (at 20\%) interacts with the ultrasound ${ }^{47}$ which allows obtaining higher analytical signals compared with the signals obtained without catalyst.

For optimized parameters the highest photocatalytic activity was obtained for modified $\mathrm{TiO}_{2}$. Nano-Ag- $\mathrm{TiO}_{2}$ as catalyst in cold vapour generation system contributed to increase of the analytical signal by about $45 \%$ and achieved relatively low limits of detection and quantification.
The catalyzed by nano-Ag- $\mathrm{TiO}_{2} \mathrm{UV}$-induced CVAAS allowed obtaining recovery of mercury in the range 95$99 \%$. The results were in good agreement with the $t$-test at a $95 \%$ confidence level of the certified values in the investigated certified reference materials.

\section{Acknowledgments}

This study was financially supported by the Poznan University of Technology (31-229/2011 DS-MK).

\section{References}

1. Barbosa, A. C.; Garcia, A. M.; de Souza, J. R.; Water, Air, Soil Pollut. 1997, 97, 1.

2. Lacerda, L. D.; Water, Air, Soil Pollut. 1997, 97, 247.

3. USEPA 823-R-10-001; U.S. Environmental Protection Agency, Office of Water: Washington DC, 2010.

4. Rooney, R. C.; Analyst 1976, 101, 678.

5. Sharma, D. C.; Davis, P. S.; Clin. Chem. (Washington, DC, USA) 1979, 25, 769

6. Sturgeon, R. E.; Mester, Z.; Appl. Spectrosc. 2002, 56, 202 A.

7. Río Segade, S.; Tyson, J. F.; Spectrochim. Acta, Part B 2003, 58, 797.

8. Poluektov, N. S.; Vitkun, R. A.; Zh. Anal. Khim. 1963, $18,37$.

9. Kahn, H. L.; At. Absorpt. Newsletter 1971, 10, 58.

10. USEPA Method 245.1; Determination of Mercury in Water by Cold Vapor Atomic Absorption Spectrometry, 1994; http://water. epa.gov/scitech/methods/cwa/bioindicators/upload/2007_07_10_ methods_method_245_1.pdf accessed in November 2011

11. Gámiz-Gracia, L.; de Castro, M. D. L.; J. Anal. At. Spectrom. 1999, $14,1615$.

12. Madden, J. T.; Fitzgerald, N.; Spectrochim. Acta, Part B 2009, 64, 925.

13. Kikuchi, E.; Sakamoto, H.; J. Electrochem. Soc. 2000, 147, 4589.

14. Wang, Q.; Liang, J.; Qiu, J.; Huang, B.; J. Anal. At. Spectrom. 2004, 19, 715.

15. Guo, X.; Sturgeon, R. E.; Mester, Z.; Gardner, G. J.; Anal. Chem. 2003, 75, 2092. 
16. Guo, X.; Sturgeon, R. E.; Mester, Z.; Gardner, G. J.; Anal. Chem. 2004, 76, 2401.

17. Sturgeon, R. E.; Willie, S. N.; Mester, Z.; J. Anal. At. Spectrom. 2006, 21, 263.

18. Zheng, C.; Sturgeon, R. E.; Hou, X.; J. Anal. At. Spectrom. 2009, 24, 1452.

19. Grinberg, P.; Sturgeon, R. E.; J. Anal. At. Spectrom. 2009, 24, 508.

20. Zheng, C.; Sturgeon, R. E.; Brophy, C. S.; He, S.; Hou, X.; Anal. Chem. 2010, 82, 2996.

21. Guo, X.; Sturgeon, R. E.; Mester, Z.; Gardner, G. J.; Appl. Organomet. Chem. 2003, 17, 575.

22. Guo, X.; Sturgeon, R. E.; Mester, Z.; Gardner, G. J.; Environ. Sci. Technol. 2003, 37, 5645.

23. Guo, X.; Sturgeon, R. E.; Mester, Z.; Gardner G. J.; J. Anal. At. Spectrom. 2005, 20, 702.

24. Guo, X.; Sturgeon, R. E.; Mester, Z.; Gardner, G. J.; Appl. Organomet. Chem. 2004, 18, 205.

25. Deng, H.; Zheng, C.; Liu, L.; Wu, L.; Hou, X.; Lv, Y.; Microchem. J. 2010, 96, 277.

26. Zheng, C.; Li, Y.; He, Y.; Ma, Q.; Hou, X.; J. Anal. At. Spectrom. 2005, 20, 746.

27. Bendl, R. F.; Madden, J. T.; Regan, A. L.; Fitzgerald, N.; Talanta 2006, 68, 1366.

28. Vieira, M. A.; Ribeiro, A. S.; Curtius, A. J.; Sturgeon, R. E.; Anal. Bioanal. Chem. 2007, 388, 837.

29. Gil, S.; Lavilla, I.; Bendicho, C.; Anal. Chem. 2006, 78, 6260.

30. Ribeiro, A. S.; Vieira, M. A.; Willie, S.; Sturgeon, R. E.; Anal. Bioanal. Chem. 2007, 388, 849.

31. López-Rouco, A.; Stanisz, E.; Matusiewicz, H.; Lavilla, I.; Bendicho, C.; J. Anal. At. Spectrom. 2008, 23, 1026.

32. Han, C.; Zheng, C.; Wang, J.; Cheng, G.; Lv, Y.; Hou, X.; Anal. Bioanal. Chem. 2007, 388, 825.

33. Yin, Y.; Qiu, J.; Yang, L.; Wang, Q.; Anal. Bioanal. Chem. 2007, 388,831 .

34. Li, Y.; Zheng, C.; Ma, Q.; Wu, L.; Hu, C.; Hou, X.; J. Anal. At. Spectrom. 2006, 21, 82.

35. Liu, Q.; Spectrochim. Acta, Part B 2010, 65, 587.
36. Xia, H.; Liu, X.; Huang, K.; Gao, Y.; Gan, L.; He, C.; Hou, X.; Spectrosc. Lett. 2010, 43, 550.

37. Khalil, L. B.; Rophael, M. W.; Mourad, W. E.; Appl. Catal., B 2002, 36, 125.

38. Tan, T. T. Y.; Yip, C. K.; Beydoun, D.; Amal, R.; Chem. Eng. J. 2003, 95, 179.

39. Doménech, J.; Muñoz, J.; Electrochim. Acta 1987, 32, 1383.

40. Kabra, K.; Chaudhary, R.; Sawhney, R. L.; Ind. Eng. Chem. Res. 2004, 43, 7683.

41. Yin, Y.; Liang, J.; Yang, L.; Wang, Q.; J. Anal. At. Spectrom. 2007, 22, 330.

42. Matusiewicz, H.; Stanisz, E.; Microchem. J. 2010, 95, 268.

43. Matusiewicz, H.; Stanisz, E.; Cent. Eur. J. Chem. 2010, 8, 594.

44. Wang, X.; Pehkonen, S. O.; Ray, A. K.; Electrochim. Acta 2004, 49, 1435.

45. Chen, D. W.; Ray, A. K.; Chem. Eng. Sci. 2001, 56, 1561.

46. Scriver,C.; Kan, M.; Willie, S.; Soo, C.; Birnboim, H.; Anal. Bioanal. Chem. 2005, 381, 1460.

47. Wang, J.; Guo, B.; Zhang, X.; Zhang, Z.; Han, J.; Wu, J.; Ultrason. Sonochem. 2005, 12, 33.

48. Hoffmann, M. R.; Martin, S. T.; Choi, W.; Bahnemann, D. W.; Chem. Rev. 1995, 95, 69.

49. Lide, D. R.; Handbook of Chemistry and Physics, Internet Version; CRC Press: Boca Raton, FL, 2005; http://www. hbcpnetbase.com accessed in May 2005.

50. Li ,X. Z.; Li, F. B.; Environ. Sci. Technol. 2001, 35, 2381.

51. Tada, H.; Teranishi, K.; Inubushi, Y-i.; Ito, S.; Chem. Commun. 1998, 2345.

52. Qamar, M.; Muneer, M.; Desalination 2009, 249, 535.

53. Chakrabarti, S.; Chaudhuri, B.; Bhattacharjee, S.; Ray, A. K.; Dutta, B. K.; Chem. Eng. J. 2009, 153, 86.

54. Bian, S.-W.; Mudunkotuwa, I. A.; Rupasinghe, T.; Grassian, V. H.; Langmuir 2011, 27, 6059.

55. Lizama, C.; Freer, J.; Baeza, J.; Mansilla, H. D.; Catal. Today 2002, 76, 235.

Submitted: August 19, 2011 Published online: November 24, 2011 